\title{
Chapter 4 \\ Lone Young Parenthood by Choice? Life Stories in Great Britain
}

\author{
Fabienne Portier-Le Cocq
}

In 2016 in the UK, there were three million (2.9) one-parent families. Women accounted for $86 \%$ of lone parents with dependent children and the remaining $14 \%$ were headed by lone fathers (ONS 2016). The rates have only marginally changed since 2001. Two per cent are young parent families.

The country has 19 million families $(18.9 \mathrm{~m})$ with dependent children (ONS 2016) and it is estimated that one child in five (22\%) is raised in a lone-parent family.

In an initial qualitative study carried out between 2001 and 2005 in England and Scotland through semi-structured in-depth interviews, a hundred young lone mothers were consulted on the circumstances of their pregnancy and their daily lives; what it is like emotionally and practically to be a young parent managing without assistance from the father and/or the family.

It appeared that for some, the relationship with the child's father had ended even before the young woman knew she was pregnant, or the break-up occurred in the first weeks or months of her pregnancy; some others had already made up their minds not to pursue the relationship with the partner or even that the relationship was no longer an option due to the biological father's substance abuse, previous or current convictions, or even abusive behaviour, putting the mother and child at potential risk.

In an ongoing follow-up survey of which the first phase was held from early September 2013 to November 2014 in England, more young mothers or pregnant young mothers being interviewed appear to be living under the same roof with the father of their child, or with another man who has become a 'stand-in father' to the child. Some have an on-and-off relationship, either with the father or with someone new, whilst some prefer, or have no other option, than to bring up the child on their own.

\footnotetext{
F. Portier-Le Cocq $(\bowtie)$

Université François Rabelais, Tours, France

e-mail: fabienne.portier-lecocq@univ-tours.fr
} 
The paper will give the latest official figures on young parenthood in Great Britain, and data on the samples of both qualitative studies carried out by the researcher. It will then look at how young lone parents fare financially, and cope emotionally and socially. Other than attending a young parents' group session in a children's centre once a week, where they have the opportunity to meet peers and share their experiences, worries, hopes and fears and can be given advice, help and support, many have no other support network available to them. The chapter will address the concerns they voice.

\section{Introduction}

In 2016, there were 18.9 million families in the UK, of which 12.7 million were married or couples in a civil partnership with or without children, and there were 2.9 million lone parents with dependent children ${ }^{1}$. Over the last two decades (19962016), lone parent families grew by $18.6 \%$ (ONS 2016). Nearly $55 \%$ of lone parents with dependent children have one child, while $13 \%$ have three or more. Fathers accounted for $22 \%$ of lone parents with non-dependent children (adult children) compared with $10 \%$ of lone parents with dependent children (ONS 2016, 5). Less than $2 \%$ of lone parents are young parents (Gingerbread n.d.). The official definition of a lone parent in Britain is unambiguous: "A lone-parent family consists of one parent, irrespective of sex, living with her or his never-married dependent children, provided these children have no children of their own" (ONS 2011). In this chapter, whenever the term "young mothers" appears, it means that they are lone parents, namely "young lone mothers". The outcome mostly described in research is negative, despite the majority of lone young mothers of the sample faring well and showing resilience at the very least.

Globally, about 16 million girls aged 15 to 19 years old and some one million underage girls (under 15) give birth every year, which represents $11 \%$ of all births worldwide. The majority of these mothers (95\%) live in low- and middle-income countries. The 2014 World Health Statistics show an average global birthrate of 15 to 19 year-olds of $49 \%$, the highest rates occuring in sub-Saharan Africa (WHO 2014). In Western Europe, the United Kingdom has the highest rate of young conception, although, since the implementation of the ten-year action plan (2000-2010) by New Labour government (1997-2010), the rates have fallen and are at their lowest since records began in 1969. In 2012, the conception rate of 15 to 17 year-old women was $27.9 \%$ conceptions (a decrease of $40.8 \%$ since 1969). Most of these conceptions are unplanned, unwanted or the result of sexual violence (ONS 2013a).

In Great Britain, girls who give birth in their teenage years are viewed as a particularly vulnerable group which poses both physical and emotional risks for the

\footnotetext{
${ }^{1} \mathrm{~A}$ dependent child is aged under 16 and lives with at least one parent, or 16 to 18 years old in fulltime education. They are not married nor living as a couple and are not parents (ONS, Families and Households in the UK:2016a, p. 2, 2016).
} 
young mothers and risks to their children in terms of low school attainment, antisocial behaviour, substance abuse and early sexual activity (The Poverty Site 2014). It has created a stigma of sorts: the poor and working poor lone young parents are viewed a social pariahs, having children in order to receive benefits or see an increase in their benefits.

This paper is based on two qualitative studies carried out in twenty-first century England and Scotland through semi-structured interviews and will endeavour to shed light on the reasons behind young conceptions and births given by interviewees while focusing on the concept of choice to become a parent. Was it their personal choice, which drove them to become a parent? Which factors intervened in their decision-making? It will also present how lone young mothers fare financially, emotionally and socially; the support, if any, they are being given within their own family or elsewhere. Lastly, the article recounts the issues young parents are confronted with and the concerns they voiced.

\section{Methodology}

Britain has been notorious for having the highest rate of young conceptions in Western Europe as well as more children living in poverty compared to other European member states, and young motherhood is considered to be a social or a public health problem. Giving a voice to young mothers and pregnant girls through qualitative studies has been the primary aim of the researcher, as the insiders' views are almost always absent from scientific literature. The corpus consists of two qualitative surveys, both conducted solely by the author. During the first one, between 2001 and 2005 at thirteen locations in England and Scotland, over one hundred young mothers or young mothers to be were interviewed. The questionnaire was composed of fifty questions under various entries. Agreement was made prior interviews that informants were free to not answer questions, should they deem some too personal and intimate given the sensitivity of the subject matter. The gathering and recording of conversations took place on a voluntary basis with respect to ethics and confidentiality (Portier-Le Cocq 2009). A large majority of lone women were interviewed on their own; very few asked for a third party to be present: a social worker, a midwife or a female friend to attend. No incentive was provided in return to the participants or their children. All interviews were recorded entirely and transcribed verbatim and the content analysis of seventy-eight interviews was performed. The underlying reasons for the attrition rate are occasional defective recording equipment or noisy environments, such as babies crying, children playing loudly, or some young mothers not being forthcoming on the issue. Two-thirds of the interviews took place in England. ${ }^{2}$ Respondents were between 12 and 19 years of age at the time of conception and $60 \%$ were underage. To the best knowledge of the author,

\footnotetext{
${ }^{2}$ The author was unable to undertake a qualitative study in Wales as she was told repeatedly that young parents were too vulnerable there.
} 
the age of consent in the United Kingdom being 16 (Sexual Offences Act 2003 and the Sexual Offences (Northern Ireland) Order 2008), the data gathered are unprecedented and innovative, if not unique. It is unlawful for an underage girl to engage in sexual intercourse - any type of sexual activity with a person under the age of 13 is strictly illegal - and a child protection issue. The first phase of the second ongoing study was conducted from September 2013 to December 2014 and commenced in the south-east region of England with thirty young parents in children's centres. Some facilities organise specific weekly sessions for parents under 25 years of age.

The scale of the sample is rather impressive if one accounts for the fact that most findings in connection with young motherhood in the United Kingdom are customarily based on fifteen interviews. Research drawing on the content analysis of a sample of one hundred and eight semi-structured interviews shows that this segment of the population is not a homogeneous group. Gathering first-hand information by meeting young mothers, giving them a voice and exploring the circumstances of these women who were marginalised by British society was the starting point of the research. A second aspect aimed to dispel the myths surrounding juvenile pregnancy and motherhood by comparing the young mothers' narratives with scientific literature and political rhetoric. In effect, the rationale put forward by successive Conservative governments in relation to teenage pregnancy and motherhood was that girls were pregnant on purpose either to access council housing or to claim and live on benefits. The reality emerging from both these large-scale qualitative studies is far more complex. Bringing out the causes and consequences of the pregnancy and understanding the reasons to carry on the pregnancy at this phase of life were further research objectives. Studying the repercussions for mothers, children and society at large was another purpose, together with looking at their living conditions on a daily basis.

The rate of young parents can seem paradoxical in a country which pioneered contraception $^{3}$, where abortion was legalised in 1967 (Abortion Act 1967) ${ }^{4}$ in Great Britain, and the Family Law Reform Act 1969 enacted that a minor over 16 could get a termination without parental consent.

\section{Lone Young Parenthood and Its Political Approach: A Success Story}

Young childbearing is a very complex issue whose causes and risk factors are multifaceted and whose outcomes can sometimes prove positive. In Great Britain, it is seen as a problem, notably when the mother is not married and no support is provided; and it is also associated with social and physical consequences which have public and private costs and have negative effects on the mother and her child.

\footnotetext{
${ }^{3}$ The birth control pill has been available since 4 December 1961. http://news.bbc.co.uk/onthisday/hi/dates/stories/december/4/newsid_3228000/3228207.stm

${ }^{4}$ The Abortion Act 1967 came into operation on 27 April 1968.
} 
According to some, it is thus a social, economic and public health problem in the case of unmarried mothers. Defining this phenomenon as a problem marginalises and stigmatises young lone mothers and their children all the more so as quantitative surveys are more frequent than qualitative ones and they do not differentiate between wanted from unwanted pregnancies. As Maureen Freely wrote in the introduction of one of her books "It's the statistics on divorce, illegitimacy, teenage pregnancy, delinquency, crime and urban blight that prove the family is in trouble, can no longer perform its social functions, needs to be saved, improved, supported, warned or admonished" (Freely 2000).

Being an underage mother ranks first in social exclusion, together with expulsion from school and homelessness. These different forms of exclusion affect $1 \%$ of the population (SEU 2001). The social exclusion notion reflects the hindrances people who live in poverty or in deprived areas are confronted with, and which prevent them from participating in society. When Tony Blair was Labour Prime Minister (1997-2007), his government implemented the Teenage Pregnancy Strategy, and one of the priorities was sexual health (The Stationery Office 1998). He commissioned a report by the Social Exclusion Unit into the causes of these problems and possible strategies. The report (SEU 1999) released in June 1999 disclosed that each year 90,000 English teenage girls (Graham 2004, 127) ${ }^{5}$ were pregnant, about $8.5 \%$ of whom were underage (7700) and 2.5\% were under fourteen (2200). Sixty per cent of conceptions resulted in live births. The government pointed out that twothirds of girls under sixteen had not had any sexual intercourse and that most had never been pregnant before turning 20 .

The two key stages of the Labour government Teenage Pregnancy Strategy (1999-2010) aimed to halve the number of under eighteen year-old conceptions in England. An intermediate objective by 2004 sought a decrease of 10 to $15 \%$, depending on the geographical areas, but was only partially reached despite joint efforts $(11 \%)$. Variations reflect the characteristics of deprivation in England. Half of all early conceptions take place in the $20 \%$ of the most disadvantaged wards, usually inner cities, and young mothers are more likely to come from a lower socioeconomic background and a large family, with parents showing little interest in their education, and/or living in a lone-parent family. Data show that girls from loneparent families whose mother did not work outside the home were more likely to become young mothers than those whose mother worked outside the home (Botting et al. 1998; Portier-Le Cocq 2009). The second goal was to increase the participation of young parents aged 15 to 19 in education, employment or training by $60 \%$. Fifteen per cent of all young people who are not in education, employment or training (NEETs) are young mothers or young pregnant girls (Local Government Association 2013); the proportion of 16-18 year-olds who were not in education, employment or training in 2011 stood at 10\% (Hagell et al. 2013).

\footnotetext{
${ }^{5}$ It means that 'in England and Wales, only about one in thirty-five young women aged 15-19 year have a baby each year, and about one in fifty have an abortion. The rates are much lower in younger teenagers. Only about one in 250 13-to 15-year-olds have an abortion and about the same number have a baby each year'.
} 
In Scotland, the national sexual and reproductive health strategy has aimed to decrease the rates of unwanted pregnancies. Reducing by $20 \%$ the conception rate of 13-15-year-old girls was the main concern, especially in disadvantaged areas. The fertility rate of 15 to 19 -year-old girls was $29.3 \%$ in 2000 compared to $17.9 \%$ in 2013 (General Register Office for Scotland 2015).

According to the 1999 report on teenage pregnancy, three key-factors stood out explaining the causes and can be summed up in one word: neglect. The first is low expectations (young people see no prospect of a job and fear that they will end up on benefit); the second is ignorance (young people lack accurate knowledge about contraception, sexually transmitted infections, what to expect in relationships and what it means to be a parent); the third is mixed messages - it seems sex is compulsory but contraception is illegal. The adult world bombards teenagers with sexually explicit messages and an implicit message that sexual activity is the norm and parents and most institutions are silent or embarrassed when it comes to talking about sex. 'If sex is not talked about, it won't happen' (SEU 1999, 7).

There is also a strong economic argument, as the costs of income support benefits for early pregnancy and motherhood was £26 million in 2009-2010 (TPA 2011) and the NHS costs associated with births, miscarriages and abortions were estimated at $£ 63 \mathrm{~m}$ a year (TPU 2003). Young lone mothers are perceived as a burden on the taxpayer, especially because they have fewer skills and opportunities for finding a job. They either choose to, or have to, drop out of school early and more than half never resume their education, even though they are below the statutory school leaving age, and therefore they have fewer or no qualifications and are of a lower level than their peers. Factors attributed to a high early pregnancy rate are low aspirations, lack of self-esteem, behavioural problems, lack of appropriate services, and a culture that supports young motherhood. The findings of the author's research show there is a myriad of reasons: poor family relationships, lack of communication, lack of early information on sexuality and contraception from parents, inefficient and inconsistent sex and relationship education in schools or the subject being broached too late, binge-drinking, a lack of self-respect and dislike of school all contribute to early pregnancies.

It is indeed a success story since funding had been ploughed into the ten-year action plan and that the policies implemented by New Labour with respect to the reduction of teenage conceptions have proved successful and fruitful. The conception rates for under 18-year-old women have been the lowest since 1969 - the first year for which abortion data was officially recorded - and the rates have kept falling. The same applies for under-16-year-old-conception rates, with a fall of $10 \%$ between 2013 and 2014, for instance (ONS 2016). 


\section{Findings: Some New Insights}

From the findings of the author's field research, there appears to be a discrepancy between real practices and stated practices. This study differentiates itself from other previous studies for three main reasons: the age of the mothers interviewed, the scale of the study, and the themes broached - the sensitive issue of the sexuality of lone young mothers has been largely overlooked in other surveys.

Young motherhood is seen as unacceptable: young lone mothers are undesirable and successive governments have done their utmost to present them in this light, although not all early pregnancies are problematic (Duncan et al. 2010). Public opinion, the media, politicians, and some academics, devote themselves to marginalising, stigmatising and constructing early motherhood as deviance, in the same way as alcohol or drug use and abuse, violence or delinquency (Portier-Le Cocq 2014). Nonetheless, for some young people, a child is an acceptable choice of life because it makes sense and values young parents (Cater and Coleman 2006, Portier-Le Cocq 2009, 2014). Except for the age at which they fall pregnant young mothers see no differences with older mothers (Sellenet and Portier-Le 2013). Besides, the medical profession has revised their opinions and shown that being young and a mother is not an obstacle on the health and obstetrics fronts (Portier-Le Cocq forthcoming). Age is important, as the possibilities and rights differ if the mother is under or over sixteen. Being an underage mother means that they are not allowed to claim nor to receive any state benefits. New Labour was the first to tackle the issue of early pregnancy within the frame of social exclusion. Its main concern was to include young parents. In England, inclusion since 2003 has meant that young pregnant girls or young mothers - from the sixth month of their pregnancy who cannot live at their parents' or their partner's home have to live in supervised semi-independent housing.

Among the explanatory causes of juvenile pregnancy given by the author's sample, binge-drinking or the excessive consumption of alcohol was occasionally mentioned. In this case, it was unprotected sex; some did not recollect having been sexually active and the denial of their pregnancy could vary. The specialised literature and the policy-makers prefer to put forward promiscuity. Young mothers are often depicted as irresponsible and immature girls. However, these young women most often fall pregnant the first time they have sexual intercourse because they are pressured by friends into having sex to belong to the group, because of casual or non existent contraception use (SEU 2001, 49) ${ }^{6}$ or are under the influence of alcohol. They have a very low awareness and poor access to emergency contraception (Braid 2008), which respondents hardly ever mentioned. There is also an assumed feeling of invulnerability - "it won't happen to me" (Lavielle 2000). The lowest levels of contraceptive use are found in the 16-19 year-olds (Hagell et al. 2013, 63). Twothirds (64\%) of 16-19 year olds are "at risk" of pregnancy - they have a sexual

\footnotetext{
${ }^{6}$ 'Between a third and a half of sexually active teenagers do not use contraception at first intercourse'. The proportion is higher than in many European countries.
} 
partner and do not use any protection - but one in ten of those with a partner do not use contraception (Lader 2008-9). Peer pressure, curiosity, conformity with others, because they feel excluded from the group if they are not sexually active are critical vehicles of pregnancy at an early age.

If we consider the negative consequences brought to light by the young lone mothers in both qualitative studies, many wished they had deferred sexual intercourse or, when they found out that they were pregnant, they had kept to their initial decision to have an abortion. Many reasons, when they had the choice, were put forward to decide against a termination: the fear of the surgical procedure, the details provided by the health professionals pertaining to abortion, the baby's biological father's or his family's pressure on the young pregnant girl, pressure from the young girl's parents, social class, and the type of antenatal examination. As far as the baby's father is concerned, a vast number of young mothers claimed that they deliberately ousted him during or after pregnancy, when it was not the young girl's parents' decision. In the corpus, unlike Scottish girls, many English young pregnant girls were thrown out of the parental home as soon as they broke the news to their family. Also, some young men shirk their responsibilities at the disclosure of the pregnancy or terminate the relationship without being informed of the pregnancy.

Contrary concerns expressed include tiredness, lack of time and energy, isolation, insufficient state benefits to live on and to bring up their baby decently, an unbalanced diet, no longer having a social life, not going out with friends or elsewhere because of the lack of money or the lack of transport or its cost for that matter. On a positive note, the author has observed a change in the decade between the two qualitative studies: a notable decline in the stigmatisation of young lone mothers. Compared with the interviews conducted in 2001-2005 when young mothers described judgmental attitudes from the general public, practitioners and services, in the most recent study in 2013-2014, no mothers reported negative and derogatory comments.

Against all odds, young motherhood can sometimes be positive and unproblematic (Scottish Parliament 2013). Relationships with the family, especially with the mother's own mother, improve with the birth of the child. The family then supports the mother and her baby financially and emotionally and they also give her advice. The young person, who was most often disaffected from school, expelled or had dropped out, resumes her studies or starts some training. The main reasons given were that she wanted to manage on her own to bring up and educate her child and no longer depend on state benefits, which are deemed insufficient. Above all, she wants to prove to others that she is a good mother and a responsible young woman, and that she can make do; she wants her child to be proud of her in the future. Mothers make plans for the future, which are often imposed by financial issues. They want to find a job so as not to depend on benefits; to look after their child and spend a lot of time together, seeing them grow up. This is inconsistent with the government views, as lone young mothers feel guilty when they work or attend school since, in their opinion, they cannot be with and take care of their child enough. 


\section{Young Mothers Speak Out!}

Drawing on the qualitative surveys conducted by the author, four main causes of early motherhood emerged, which are personal, social, economic and environmental (family). The causes and risk factors include risk behaviours, education, family and social circumstances. The family and the community disengagement are essential agents.

When summarising risk factors with respect to the sample, they encompass poverty, being in or leaving care whether it is in an institution, a foster family or with adoptive parents, casual sexual relationships, being the daughter of a young mother, living in a large family, and not being in education, employment or training (NEET). Underachieving at school before the age of sixteen without any qualifications and living with parents who show little interest in their education are other causes together with mental impairment, psychological problems, low self-esteem, peer pressure and sexual abuse or rape in their pre-teens.

"How old were you when you first had intercourse? - Um, about (thinking) 10.

I was forced into it.

Was he older? - Yes. He was about 35.

You were raped... - Yeah, but I have told none, except my boyfriend, so... He's in prison now.

How old were you when you first consented to have sex? - Um, if you do not include the rape at 10 , I was 12 or $13 . "$

Mel, ${ }^{7}$ nearly 16, mother to a six-month-old child.

"When did you become pregnant? - Um, actually I was raped in my country, that's why I came here as asylum seeker so I was pregnant in October, but I didn't know that, cos I was raped in August. So I didn't know until January the following year that I was pregnant.

How advanced was your pregnancy? - Um, I was, I think six months pregnant.

We went to another organisation and they said it was too late for me to have an abortion, so they said it's risky.

Would you have had an abortion otherwise? - Um, in my country they don't recommend that, because in my country if you do that they put you in prison for at least a year or something, yeah. But in my situation, maybe I could do that because I didn't have any choice because of my age. I wanted to study; I could do that but it was too late for me to do that. And also I just found that I was having twins so I could have done that.

Did you consider having the baby adopted? - No, I couldn't do that. They told me about that but I couldn't give my baby to someone else."

Anna, 17, mother to a thirteen-month-old baby.

Early motherhood is the result of a complex conjunction of factors, one of which is growing up in poverty. However, the most prosperous areas also have higher early pregnancy rates than the average of the European countries. The country's geographical areas along with demographics are important and there are geographical

${ }^{7}$ All names have been changed. 
variations too (Arai 2009, 25). In 2000, the juvenile pregnancy rate in Richmondupon-Thames was $19,4 \%$ o while it was five times higher $(89,8 \%$ o $)$ in Hackney. Young parenthood concentrates in areas characterised by social exclusion and deprivation (mining, former industrial and seaside areas).

Coastal and some hinterland areas show conception rates, which are higher than the national average. The reasons are isolation in rural areas and the fear of being seen and talked about when/if they buy contraceptives at the pharmacy counter, whereas on the coast, leisure activities and business give a sense of hedonism (Bell et al. 2004). As an explanation for this statement, the carnival atmosphere due to fairs, the pier and video arcades are propitious opportunities and venues to meet seasonal workers and people in general, hence transient relationships. To cap it all, casual unprotected sex, alcohol and drug consumption, and abuse are further elements. Furthermore, researchers reached the conclusion that by working in the leisure industry under sixteen year-old girls were accustomed to attracting older men in pubs and clubs and that youths were under the impression of being used by the demands of the local economy.

Young mothers have lived in broken families, reconstituted families, poor household or lone-parent families predominantly headed by mothers. They very often moved out, hence changes of schools and a poor level of education for mothers or their own mothers. They had sexual intercourse when very young - sometimes not of their own accord (CSJ 2014; Barter et al. 2009; Coy et al. 2013) - and either did not use or only occasionally used contraception. Three-quarters of the interviewees had had sexual intercourse before the age of sixteen, and half of the sample said their pregnancy was unplanned. Half of the sample said they did not use contraception when they first had sex.

"How many boyfriends have you had so far? - I started having sex at 11 with older boyfriends, like 15."

Chantelle, 22, mother to a nineteen-month-old child and a four-and-a-half-year-old child.

Alcohol abuse or binge-drinking, which has been ignored by government surveys, was a factor mentioned a few occasions, and most often the young women had no recollection of what had happened as both extracts below demonstrate.

"I can't remember. I was drunk when I had sex, Jesus Christ!

I fell pregnant when I was thirteen and that was the first time

I can't even remember."

Daisy, 16 and two months, mother to a two-and-a-half-year-old child.

"How old were you when you had your first sexual intercourse? - 14. Um (laugh), um, I cannot remember, I was kind of drunk."

Jasmine, 15 and two months, mother to an eight-month-old child.

The Institute for Public Policy Research also stated that early pregnancy was part and parcel of British culture. Researchers clearly showed that British young people were sexually active at a younger age than their European counterparts and that they had more casual sex. This can be explained by the increase in time spent with their peers in non-structured activities such as hanging out in the streets and not being 
under their parents' supervision, especially in deprived communities rather than time spent with parents (quality time). Idleness and a feeling of a lack of parental control are sources of early pregnancy.

The young British are supposedly more interested in consuming and spending long hours on the Internet without any parental control, and research shows that they are exposed to more sexual messages via the use of the Internet or in the media (Margo et al. 2006, 171-72). These messages promote sexual activity but never allude to contraception or HIV transmission risks. According to Carrys Lovering (2005, 134-35), young people wish they were busier and had venues at which to meet (Barry 2005). Some young women wished that youth centres had longer opening hours, that they were informed of the planned activities, and that trips and artistic projects and information technology training were organised as well. Young people are keen on outdoor activities such as skateboarding, for instance, but they said they had nowhere to practice and grown-ups complained if they skated in the streets.

Monica Barry said that youths from deprived communities and, especially the young unemployed, do not go to leisure centres geared to them because of the cost. As a consequence, groups who need this are those who are deprived of this amenity for economic reasons. She also said that young mothers go to young mothers' groups such as Young Women Christian Association because they are free. If there were no such services or Sure Start children's centres, for instance, lone young mothers would not meet anyone, above all because of the lack of childcare or its cost.

Young women have nothing to lose if they get pregnant, as they are often disaffected from education and their achievement is low as well as their career expectations. Becoming a mother is a way of being acknowledged within one's peers, family circle and society, and of reaching adulthood. Having no qualifications, being disengaged from school and having no career prospects, having a baby is thus an acceptable option. Social background and class are crucial factors in the decisionmaking process. Young girls who come from affluent backgrounds and aim to carry on with their studies at university are seven times more inclined to have a termination than their less affluent counterparts (BPAS 2000).

\section{Living on a Tight Budget: The Big Issue}

State benefits provide only enough for survival and young lone mothers struggle to make ends meet. Receiving income support, which is a means-tested benefit, is an indicator of poverty in the UK. Compared to older mothers, who had a child at 24 or over, the percentage of young lone mothers who receive income support is three times more. The Department for Work and Pensions figures show that around 70\% of mothers aged 16-19 claim income support. Most of the time the young lone mothers of this study had no idea which benefits they could claim or what their parents received for them and their children, which shows they did not get pregnant to get money from the State (Allen and Bourke-Dowling 1998). 
"Do you get any benefits from the state? - My mum claims.

Do you know what she gets? - Um, she gets a $£ 500$ grant for us to get all the baby stuff, and I think she got money for clothes for us as well; when you get bigger you need clothes. I don't know what'll happen when the baby's born, and what the money I'll get, I don't know."

Debora, 15 years old and three months, mother to a 4 month-old child.

Young lone mothers may be entitled to benefits depending on their age, whether they are living with their parents or not, and if their parents work or not. Sixty per cent of underage mothers were not entitled to claim any benefits. They were thus dependent on their partner, if he was still around, or their parents if they had not forced them to leave home. They were only entitled to weekly Healthy Start vouchers to help with the cost of baby milk, milk, fruit and vegetables. You must be 16 or over to claim Income Support, which is allocated to lone parents who are not working (or working fewer than 16 hours a week) and whose youngest child is under five. The map of young pregnancy in Britain is the map of poverty and deprivation.

Another crucial issue for young lone mothers is that childcare can prove nonexistent or onerous and hinder the process of getting young mothers into work.

"I could [stay at school] as long as I had childcare but that was the problem because we didn't have a lot of money to pay for a child-minder to look after the baby when I went to school, but then it would be a problem with coming home with homework and having to look after the baby at the same time because you don't get free work periods or free time or teachers at that school. There was nothing really there for me that they could help me with."

Helen, 15 years 10 months, mother to a 9 month-old child.

Hilary Graham and Elizabeth McDermott (2006, 30) underlined that families help ensure that their daughter and her child are provided for materially and with a home, among others. In the case of the breakdown of the links following the announcement of the pregnancy, it is very difficult for young mothers to overcome the financial and social handicaps of being a young and poor lone mother. If the young couple has separated and they have built up a friendly relationship, the baby's father can provide the young mother with space, support and things for the baby instead of money.

“He takes Mike like all day on Sunday but he doesn't help financially or anything.

-Yes, yes, he sees him when he wants.

So, how do you manage financially? - He helps us all a lot.

He gives you maintenance? - Yeah. No, he just gives it straight to me. He helps out with buying nappies and things like that and then he gives us money for when I go out."

Fiona, 17 years 10 months, mother to a two year-old whose 21-year-old father is a factory worker.

"Almost every day like he comes from work to my house. He stays for a bit, but if not everyday he takes the baby to the crèche on Thursdays and Fridays in the morning. I have to wake up early, and he comes on Sundays to take it. He goes to his mum's so he takes it with him, and sometimes during the week, he just picks the baby up from the crèche, so I wouldn't be able to say exactly how many times.

Does he help you financially? - I'm always asking for things, then he helps.

Every week he gives me money for the baby's crèche and other things.

Still now that you split up... - Yeah."

Megan, 19, mother to a 9 month-old baby whose father is 24 and a receptionist. 


\section{A Roof Over My Head}

It is generally not true that girls get pregnant in order to get a council flat; $90 \%$ of young mothers live in their parents' home or the home of their partner's parents and there is also evidence of planned juvenile pregnancies.

The thrust of the New Labour Government's message was that young parents needed support to maintain a tenancy and live independently. This includes teaching them how to cook and how to budget. All lone young parents under 18 who cannot live with their parents or partner should be in supervised supported accommodation and they should not be given any independent tenancies without support. In July 2013, the 40 Group - the Tories who hold the most marginal seats in Parliament contemplated depriving young lone mothers of council housing or housing benefit in a bid to reduce early pregnancy. All benefits would be conditional upon young lone mothers living at the parental home or in supervised hostel accommodation.

In the sample of the first qualitative study, 50\% of mothers lived at their parents' or relatives'. One-fifth lived in independent housing, two-thirds of whom lived in supported accommodation with or without the child's father. The discrepancy between England and Scotland in this respect is that early pregnancy and motherhood seem to be more acceptable in Scotland, especially in the most deprived area, or the Scots seem more understanding or more responsible parents. Moreover, in the sample, no young pregnant girls were asked never to return home as was often the case in England. Young Scottish mothers tend to live at their parents' until the baby is a toddler then move to their own independent housing with their child. The lodging always has to be close to their parents' home and they go and see their parents on a daily basis, which is reminiscent of M. Young and P. Willmot study's findings (1957).

"Just up the road from my mum and dad's."

Sara, 17 and 9 months, mother to a 9 month-old baby.

"Yes, across the road from my mum.

[...] when you had the baby did you live at your mum's or... I stayed with my mum for a year but then I moved out 'cos like, my sister, Muriel, my sister lived there as well and she's had a baby as well, so it was really overcrowded. So then I moved out, got my own house."

Kirsty, 19, mother to a three year and 6 month-old child.

Overcrowded housing is also a reason for having to live on one's own in council housing.

"Just, I have to scrape it together... I live on me own with Davy. I have moved from my mum and dad's house. I'm getting House Benefit.

And how much is it? - Um, £42 a week.

And is it OK for the rent? Sometimes.

Do you get Child Benefit and Income Support as well? — Yeah. $£ 30$ on nappies and wipes and baby food, $£ 30$ on gas and heating; so it doesn’t leave a lot of money for food for me or clothes or so... 
And why is it you left your parents' home? - Because there was eight of us and there are three bedrooms. So there wasn't enough room."

Sara was 16-and-a-half at the conception of her baby who was 9 months old at the time of the interview.

Young lone mothers very often ask to live in the vicinity of childcare facilities so as to avoid spending money, time and energy on transport. David Pevalin $(2003,8)$ said that young mothers' children were the first to be affected by residential mobility, i.e. they could live in four different places or more before they turn ten.

\section{Did You Say Social Life?}

Preferably, young lone mothers should not move out. They have to organise their new life as mothers, they live on a tight budget and have at least one child to nurture. They are sometimes put up in temporary accommodation such as bed and breakfast, a mother and baby home or accommodation for the homeless. Once they have a roof over their head, their mobility is limited, they live in poverty, their freedom and social life dwindle and they spend long hours on their own trying to entertain themselves and their baby in complete isolation. They are confined to their home and their close neighbourhood, which could explain their wish to live near their family, which in turn increases the difficulties in finding accommodation.

As for their social life, despite the problems, half of the sample said they went out regularly, but $15 \%$ had never been out since the baby was born, which could have been for months. Ten per cent seldom went out because of the lack of money or tiredness. Social activities may include going to the pub, drinking or binge-drinking, eating out, hanging out with friends, going to the pictures and going food-shopping. For those who have no social life at all, watching television is their only outlet.

"- I don't go out quite a lot. I'm quite happy watching some TV."

Abigail, 19, mother to two-year-old twins.

"There's a park just where I live where we meet all and we might go to the pictures or go for some tea but there's just times we are just all together so that I'm making most of the time while I've got it."

Helen, 15 years and 10 months old, mother to a 9 month-old baby

Over time, visits and going out with friends or relatives become a rarity as they lack money, time, energy and support, and young lone mothers have a different pace of life from their friends when they become parents. Isolation is what sometimes makes them regret having a child. Still, all the negative points previously developed are offset by their pride and fulfilment of being parents. Childbearing and childrearing are turning points in young women's life for the better. With maternity, they have a goal in life, more self-esteem and are now respected by their parents who consider them adults. Young lone mothers can and want to rebuild their lives through 
their resilience and in order to show others that they are not the inadequate or failing mothers they are alleged to be. Yet they do need emotional and social wherewithal to achieve that.

\section{Conclusion}

This chapter has aimed to call into question theory in young mothers' studies through systematic content analysis and young mothers' everyday lives as far as their social and private lives are concerned. Despite positive and life-enhancing attitudes to motherhood, what they lack most is support and back-up, encouragement, money and social network. A striking comparison between the two qualitative studies conducted by the author has so far shown that young fathers in the south-east of England are more involved in "being there for" the mother and the child. They support their family by working, living under the same roof, attending young parents' sessions in Sure Start family centres, and caring for the mother and child.

The interviews run counter to generally held views and the official line of the Conservative Governments that young British women are scheming to have a child to jump the house queue and live on state benefits. In Great Britain and the other industrialised countries, the perception of young lone mothers is negative partly because they drop out of school and then have difficulty in finding a job. The blatant lack of childcare and its prohibitive cost is another barrier to their entering the labour market. For the majority of young women who grow up in a country of the OECD ${ }^{8}$, the norm and the expectations are to study, have a job with a household and two salaries, defer a pregnancy then have a small family. In this respect, early motherhood has become a significant issue because there is a discrepancy between the majority of the population and the young mother who is seen as different (Sellenet and Portier-Le Cocq 2013). Moreover, even if the early pregnancy rate has seen a $41 \%$ reduction in under-18 conceptions and an even steeper reduction in births by $46 \%$ since 1998, the major change since the 1960s has been the high number of babies born outside marriage, leading to more one-parent households in Great Britain as well as the rise of house-sharing since the 1980s. In 1981, 55\% of births involving young mothers were within marriage compared to $12 \%$ in 1996 (Botting et al. 1998). Sixty per cent of young mothers are lone mothers (DCSF 2007, 8). Girls who become mothers, either no longer attend school, are expelled or disaffected. At the birth of their child, most only want to care for their child and are reluctant to entrust the child to the care of a third party. The determination of past and present governments to put young mothers into work, education or training is incompatible with that perception. Another paradox lies in the fact that governments want to encourage young lone mothers to spend time with their child while also encouraging them to find a job so as to be less of a financial burden to the taxpayer.

\footnotetext{
${ }^{8}$ Organisation for Economic Cooperation and Development.
} 
The causes and outcomes of juvenile conceptions and motherhood are a cause for concern in Great Britain, but to the outsider the main efforts of governments concentrate on preventing young motherhood, while, it seems, passing over in silence disturbing and upsetting factors such as binge-drinking among youth and the discrepancy between income distribution and inequality at large, which are altogether paramount. Assistance brought to young lone parents in terms of support had thus far not been a priority on the political agenda. Yet it should be borne in mind that the children of young parents and young parents themselves are tomorrow's citizens and taxpayers and that they should not be scapegoats.

Acknowledgements This paper benefited from the support of the Swiss National Centre of Competence in Research LIVES - Overcoming Vulnerability: Life Course Perspectives, which is financed by the Swiss National Science Foundation (Grant number: 51NF40-160590).

\section{References}

Allen, I., \& Bourke-Dowling, S. (1998). Teenage mothers: Decisions and outcomes. London: Policy Studies Institute.

Arai, L. (2009). Teenage pregnancy: The making and unmaking of a problem. Bristol: The Policy Press.

Barry, M. (Ed.). (2005). Youth policy and social inclusion: Critical debates with young people. Abingdon: Routledge.

Barter, C., McCarry, M., Berridge, D., \& Evans, K. (2009). Partner exploitation and violence in teenage intimate relationships. London: NSPCC.

Bell, J., Clisby, S., Craig, G., Stanley, N., Measor, L., Petrie, S. (2004, April). Living on the Edge: Sexual behaviour and young parenthood in rural and seaside areas. London, Teenage Pregnancy Unit, Department of Health.

Botting, B., Rosato, M., \& Wood, R. (1998). Teenage Mothers and the Health of Their Children, Population Trends, (93), Autumn, 21.

Braid, M. (2008, July 18). Sex education: Are we getting enough? The sex factor. The Guardian.

British Pregnancy Advisory Service. (2000). Aspiration and ambition are key factors in teenage abortion decisions. Retrieved December 14, 2014, from http://www.bpas.org.

Cater, S., \& Coleman, L. (2006). 'Planned' teenage pregnancy: Perspectives of young parents from disadvantaged backgrounds. Bristol: Policy Press.

Centre for Social Justice. (2014). Fully committed? How government could reverse family breakdown. London: Centre for Social Justice.

Coy, M., Kelly, L., Elvines, F., Garner, M., \& Kanyeredzi, A. (2013, November). Sex without consent? I suppose that is rape: How young people in England understand sexual consent. London: Office of the Children's Commissioner.

Department for Children, Schools and Families. (2007). Teenage pregnancy next steps: Guidance for local authorities and primary care trusts. London.

Duncan, S., Edwards, R., \& Alexander, C. (Eds.). (2010). Teenage pregnancy: What's the problem? London: The Tufnell Press.

Family Law Reform Act. (1969). Consent by persons over 16 to surgical, medical and dental treatment (c.46, section 8). Retrieved from http://www.legislation.gov.uk/ukpga/1969/46/section/8

Freely, M. (2000). The parent trap. Children, families and the new morality (pp. 4-5). London: Virago Press.

Gingerbread (n.d.). Statistics. Retrieved January 12, 2016, from Gingerdread website, http://www. gingerbread.org.uk/content/365/Statistics 
Graham, H., \& McDermott, E. (2006). Qualitative research and the evidence base of policy: Insights from studies of teenage mothers in the UK. Journal of Social Policy, 35(1), 30.

Graham, P. (2004). The end of adolescence (Vol. 127). Oxford: Oxford University Press.

Hagell, A., John, C., \& Fiona, B. (2013). Key data on adolescence. London: Association for Young People's Health.

Lader, D. (2008/2009). Contraception and sexual health. London: ONS.

Lavielle, M. (2000, December 9). Aspects particuliers des IVG chez les mineurs. In D. Marcelli \& P. Alvin (Eds.), Grossesse et Adolescence : 2è journée de Médecine et Santé de l'Adolescent (pp. 46-49). Poitiers: FIREA.

Local Government Association. (2013, April 30). Tackling teenage pregnancy: Local government's new public health role. Retrieved May, 2017, from http://cdn.basw.co.uk/upload/ basw_104235-7.pdf

Lovering, C. (2005). Postcript on Leisure. In M. Barry (Ed.), Youth policy and social inclusion: Critical debates with young people (pp. 134-135). Abingdon: Routledge.

Margo, J., Dixon, M., Nick, P., \& Reed, H. (2006). Freedom's orphans: Rising youth in a changing world. Institute for Public Policy Research, 171-172.

National Records of Scotland. (2014a). Vital events reference tables 2013: Section 3: Births. Retrieved from https://www.nrscotland.gov.uk/statistics-anddata/ statistics/statistics-by-theme/ vital-events/general-publications/vital-events-reference-tables/2013/section-3-births

National Records of Scotland. (2014b). Table 3.5: Fertility rates by age of mother and marital status of parents, Scotland, 1971 to 2013. Retrieved May, 2017, from https://www.nrscotland. gov.uk/files//statistics/ve-ref-tables-2012/rev-table-3-5.pdf

Office for National Statistics. (2011). General lifestyle survey, definitions and terms. Retrieved December 14, 2014, from https://www.ons.gov.uk/peoplepopulationandcommunity/ personalandhouseholdfinances/incomeandwealth/compendium/generallifestylesurvey/ 2013-03-07

Office for National Statistics. (2013a). Labour force survey, UK families by type and presence of children (thousands). Retrieved 14 Dec 2014 from https://www.ons.gov.uk.

Office for National Statistics. (2013b April). Teenage pregnancies at lowest level since records began. Retrieved December 14, 2014, from http://webarchive.nationalarchives.gov. uk/20160105220309/http://www.ons.gov.uk/ons/rel/vsob1/conception-statistics--englandandwales/2011/sty-conception-estimates-2011.html

Office for National Statistics. (2013c). Births by mothers' usual area of residence in the UK: 2012. Retrieved December 14, 2014, from https://www.ons.gov.uk/peoplepopulationandcommunity/ birthsdeathsandmarriages/livebirths/datasets/birthsbyareaofusualresidenceofmotheruk

Office for National Statistics. (2014, October 15). International comparisons of teenage births. Retrieved December 14, 2014, from http://webarchive.nationalarchives.gov. uk/20160105202748/http://www.ons.gov.uk/ons/rel/vsob1/births-by-area-of-usual-residenceof-mother-england-and-wales/2012/sty-international-comparisons-of-teenage-pregnancy.html

Office for National Statistics. (2016a). Families and households. London: Data Analysis Unit. Retrieved December 14, 2014, from https://www.ons.gov.uk/peoplepopulationandcommunity/ birthsdeathsandmarriages/families/datasets/familiesandhouseholdsfamiliesandhouseholds

Office for National Statistics. (2016b). Conceptions in England and Wales: 2014. Retrieved December 14, 2014, from https://www.ons.gov.uk/peoplepopulationandcommunity/ birthsdeathsandmarriages/conceptionandfertilityrates/bulletins/conceptionstatistics/2014

Office for National Statistics (n.d.). Retrieved 12 Jan 2016 from Office for National Statistics website, http://www.ons.gov.uk.

Pevalin, D. J. (2003, October). Outcomes in childhood and motherhood by mother's age at birth'. In J. Ermisch \& D. J. Pevalin, (Eds.), Does a 'teen birth' have longer-term impacts on the mother? Evidence from the 1970 British Cohort Study. ISER Working Papers Number 200328, University of Essex. 
Portier-Le Cocq, F. (2009). Maternité et sexualité des adolescentes, voix anglaises et écossaises. Rennes: Presses universitaires de Rennes.

Portier-Le Cocq, F. (2014, septembre). The Demonisation and Social Control of Teenage Mothers in 21st Century Britain. E. Bell \& G. Christoph (dir.), Labelling the Deviant: Othering and Exclusion in Britain From Past to Present, Revue française de civilisation britannique (RFCB), Vol XIX, n1, 185-204.

Portier-Le Cocq, F. (forthcoming). The health of British teenage parents and their children. In F. P.-L. Cocq (Ed.), Fertility, health and lone parenting: European contexts, Routledge studies in the sociology of health and illness series. Abingdon: Routledge.

Scottish Parliament. (2013, June 19). Fifth report 2013 (Session 4): Report on inquiry into teenage pregnancy, HC/S4/13R5. Retrieved May, 2017 from http://www.parliament.scot/S4_ HealthandSportCommittee/Reports/heR-13-05w.pdf.

Sellenet, C., \& Portier-Le, C. F. (2013). Maternité adolescente: Le temps bousculé,. In M. Robin \& A.-M. Fontaine (Eds.), La Parentalité tout au long de la vie. Revue internationale de l'éducation familiale, $n^{\circ} 33,17-36$.

Social Exclusion Unit. (1999, June). Teenage pregnancy: Report by the Social Exclusion Unit presented to Parliament by the Prime Minister by command of Her Majesty, Cm 4342.

Social Exclusion Unit. (2001, March). Preventing social exclusion. Retrieved May, 2017, from http://www.bris.ac.uk/poverty/downloads/keyofficialdocuments/Preventing\%20Social\%20 Exclusion.pdf

The Poverty Site. (2010). UK: Underage pregnancies. Retrieved December 14, 2014, from http:// www.poverty.org.uk/24/index.shtml

The Stationery Office. (1998, February). Our healthier nation: A contract for health, presented to parliament by the secretary of state for health by command of her majesty, Cm 3852.

Teenage Pregnancy Associates. (2011, February). Teenage pregnancy: The evidence. London.

Teenage Pregnancy Strategy Evaluation. (2003). Annual report synthesis 2002. London: Teenage Pregnancy Unit, DfES.

WHO. (2014, September). Adolescent pregnancy, Fact sheet $n^{\circ} 364$.

Young, M., \& Willmott, P. (1957). Family and kinship in East London. London: Penguin Books.

Fabienne Portier-Le Cocq is Professor of Contemporary British Studies at the Faculty of English Studies at the University François Rabelais of Tours, France. Her research interests include teenage parenthood in Great Britain and France; lone mothers, motherhood, violence against women and girls, care leavers, social issues, qualitative studies and comparative European studies.

Open Access This chapter is licensed under the terms of the Creative Commons Attribution 4.0 International License (http://creativecommons.org/licenses/by/4.0/), which permits use, sharing, adaptation, distribution and reproduction in any medium or format, as long as you give appropriate credit to the original author(s) and the source, provide a link to the Creative Commons license and indicate if changes were made.

The images or other third party material in this chapter are included in the chapter's Creative Commons license, unless indicated otherwise in a credit line to the material. If material is not included in the chapter's Creative Commons license and your intended use is not permitted by statutory regulation or exceeds the permitted use, you will need to obtain permission directly from the copyright holder.

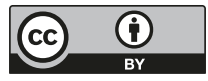

